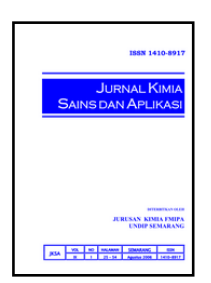

\title{
Pengaruh Waktu pada Pembentukan Kalsium Fosfat dengan Sistem Membran Selulosa Bakterial
}

\author{
Febriani Sinambela ${ }^{a}$,Tri Windarti ${ }^{*}$, Parsaoran $^{a}$ \\ a Physical Chemistry Laboratory, Chemistry Department, Faculty of Sciences and Mathematics, Diponegoro University, Jalan Prof. \\ Soedarto, Tembalang, Semarang \\ * Corresponding author: tri.windarti@live.undip.ac.id
}

Article Info

Keywords:

effect of time, calcium phosphate, membrane cellulose bacterial, bioimplant

\section{Abstract}

Calcium phosphate is a compound commonly used as bio-implant material due to its biocompatible, bioactive and osteo-conductive. Bacterial cellulose membrane system is a method that can be used in the formation of calcium phosphate. This study was carried out on several steps which were a synthesis of bacterial cellulose used $1000 \mathrm{~mL}$ coconut water media, $100 \mathrm{~g}$ sugar and 0,6 g diammonium sulphate for incubation $100 \mathrm{~mL}$ Acetobacter Xylinum bacterial, synthesis of calsium fosfat with variation of time of 5,6 , 12,24 , and 48 hours used bacterial cellulose membrane system, and analysis of synthesis product used FTIR and XRD. According to FTIR and XRD, analysis calcium phosphate formation with variation time of 5,6 , and 24 hours, the types of calcium phospate formed were calcium hydrogen phosphate dyhidrate (CHPD) $\left[\mathrm{CaHPO}_{4} \cdot 2 \mathrm{H}_{2} \mathrm{O}\right]$, tricalcium phosphate $\left[\mathrm{Ca}_{3}\left(\mathrm{PO}_{4}\right)_{2}\right]$, carbonat hydroxyapatite $\left[\mathrm{Ca}_{10}\left(\mathrm{PO}_{4}\right)_{5}\left(\mathrm{CO}_{3}\right)(\mathrm{OH})_{2}\right]$, and hydroxyapatite $\left[\mathrm{Ca}_{10}\left(\mathrm{PO}_{4}\right)_{6}(\mathrm{OH})_{2}\right]$ while 12 and 48 hours, types of calcium phospate formed were calcium hydrogen phosphate dyhidrate, tricalcium phosphate, and hydroxyapatite. The longer the time, the greater the size of the crystallites of CHPD as the main product for 5 hours gives $30.28 \mathrm{~nm}$, while for variations of $6,12,24$, and 48 hours give the crystallite sizes of $32,60 \mathrm{~nm}$ and $33,90 \mathrm{~nm}$ respectively.

\section{Abstrak}

Kalsium fosfat merupakan senyawa yang biasa digunakan sebagai material bio-implan karena bersifat biokompatibel, bioaktif dan osteokonduktif. Sistem membran selulosa bakterial adalah metode yang dapat digunakan dalam pembentukan kalsium fosfat. Pembuatan kalsium fosfat dilakukan melalui beberapa tahap, meliputi sintesis selulosa bakterial menggunakan $1000 \mathrm{~mL}$ media air kelapa, $100 \mathrm{~g}$ gula pasir dan 0,6 $\mathrm{g}$ diamonium sulfat untuk membiakkan $100 \mathrm{~mL}$ starter bakteri Acetobacter Xylinum, pembuatan kalsium fosfat dengan variasi waktu 5, 6, 12, 24 dan 48 jam menggunakan sistem membran selulosa bakterial dan analisis produk sintesis menggunakan FTIR dan XRD. Berdasarkan analisis FTIR dan XRD, pembentukan kalsium fosfat menggunakan membran selulosa bakterial, pada variasi waktu 5, 6, dan 24 jam menghasilkan kalsium hidrogen fosfat dihidrat (CHPD) $\left[\mathrm{CaHPO}_{4} \cdot 2 \mathrm{H}_{2} \mathrm{O}\right]$, trikalsium fosfat (TCP) $\left[\mathrm{Ca}_{3}\left(\mathrm{PO}_{4}\right)_{2}\right]$, karbonat hidroksiapatit (CHA), dan hidroksiapatit $(\mathrm{HA})\left[\mathrm{Ca}_{10}\left(\mathrm{PO}_{4}\right)_{6}(\mathrm{OH})_{2}\right]$ dan variasi waktu 12 dan 48 jam adalah CHPD, TCP dan HA. Semakin lama waktu pembentukan kalsium fosfat, fase kalsium fosfat semakin semikristalin. Selain itu, semakin lama waktu, ukuran kristalit CHPD sebagai produk utama cenderung semakin besar yaitu variasi waktu 5 jam sebesar 30,28 nm, variasi waktu 6,12, 24 jam sebesar 32,60 nm, dan variasi waktu 48 jam sebesar 33,90 $\mathrm{nm}$. 


\section{Pendahuluan}

Kalsium fosfat adalah kelompok mineral yang mengandung ion kalsium $\left(\mathrm{Ca}^{2+}\right)$, ortofosfat $\left(\mathrm{PO}_{4^{3-}}\right)$, pirofosfat $\left(\mathrm{P}_{2} \mathrm{O}_{7^{4-}}\right)$, hidrogen $\left(\mathrm{H}^{+}\right)$, dan hidroksida $\left(\mathrm{OH}^{-}\right)$ [1]. Kalsium fosfat biasa digunakan sebagai material bio-implan karena bersifat bersifat biokompatibel, bioaktif dan osteokonduktif. Bioaktivitas material kalsium fosfat bergantung pada kemurnian, ukuran kristal, morfologi, konsentrasi, $\mathrm{pH}$, serta temperatur. Sintesis material kalsium fosfat (CaP) terutama kalsium hidrogen fosfat dihidrat (CHPD), trikalsium fosfat (TCP), dan hidroksiapatit (HA) secara luas telah dipelajari dan hasilnya digunakan sebagai biomaterial, drug delivery, antiseptik, maupun anti kanker [2, 3].

Besarnya potensi penggunaan kalsium fosfat dalam bidang biomedik menyebabkan berkembangnya beberapa teknik sintesis seperti reaksi zat padat, proses microwave, hidrotermal, pengendapan basah, sol-gel, spray pirolisis, dan metode mekano-kimia [4]. Setiap metode tersebut memiliki kekurangan dan kelebihan pada produk kalsium fosfat yang dihasilkan. Berdasarkan adanya kekurangan dari metode penelitian di atas, maka perlu adanya metode lain dengan menggunakan sistem membran untuk pembuatan kalsium fosfat.

Sistem membran adalah sistem yang menggunakan pembatas selektif tipis berpori sehingga mampu melakukan beberapa proses perpindahan dengan menggunakan perbedaan konsentrasi, potensi listrik dan tekanan sebagai driving force [5]. Material yang dapat digunakan sebagai sistem membran adalah selulosa bakterial.

Selulosa bakterial adalah sejenis polisakarida mikroba yang dihasilkan melalui fermentasi air kelapa menggunakan Acetobacter Xilynum berupa benangbenang dan polisakarida membentuk jalinan yang terdiri dari serat selulosa. Berdasarkan penelitian Surma-Ślusarska $d k k$. [6], membran selulosa bakterial yang diperoleh dari kultur Acetobacter Xylinum memiliki ukuran pori rata-rata antara 70 - $200 \mathrm{~nm}$ dan kekuatan mekaniknya tinggi. Membran selulosa bakterial juga memiliki sifat kemurnian tinggi, derajat kristalinitas yang tinggi, dan mempunyai sifat permeabilitas yang selektif [7]. Karakteristik tersebut menyebabkan membran selulosa bakterial dapat digunakan dalam pembuatan kalsium fosfat. Pembuatan kalsium fosfat dengan menggunakan membran selulosa bakterial, diharapkan akan menghasilkan produk kalsium fosfat dengan karakteristik spesifik seperti keseragaman jenis, fase dan ukuran bulir kristal kalsium fosfat.

Reaksi pembentukan kalsium fosfat pada sistem membran dipengaruhi oleh beberapa faktor seperti ukuran pori membran, jenis reaktan, konsentrasi reaktan, $\mathrm{pH}$, dan waktu kontak. Pada penelitian ini dilakukan variasi waktu untuk mengetahui pengaruh waktu terhadap berat produk, jenis, fase, dan ukuran bulir kristal.

\section{Metodologi}

\section{Sintesis Selulosa Bakterial}

Bakteri Acetobacter xylinum dimasukkan ke dalam media air kelapa (100 mL : $1000 \mathrm{~mL}$ ). Media air kelapa yang digunakan terdiri dari $1000 \mathrm{~mL}$ air kelapa, $100 \mathrm{~g}$ gula pasir, $0,6 \mathrm{~g}\left(\mathrm{NH}_{4}\right)_{2} \mathrm{SO}_{4}$. Proses pembuatan dilakukan pada $\mathrm{pH}$ 3,5 dan pengaturan $\mathrm{pH}$ dilakukan dengan menambahkan $18 \mathrm{~mL} \quad \mathrm{CH}_{3} \mathrm{COOH} \quad 80 \%$. Inkubasi dilakukan sampai diperoleh selulosa bakterial dengan ketebalan $\pm 1 \mathrm{~cm}$.

\section{Pembuatan Membran Selulosa Bakterial}

Selulosa bakterial hasil fermentasi berupa hidrogel selanjutnya dicuci dengan akuades hingga $\mathrm{pH}=6$. Membran dibuat dengan cara menempatkan selulosa bakterial pada dua plat kaca dan diberi beban sekitar 6 kg selama 24 jam sampai membentuk lembaran tipis, selanjutnya dikeringkan pada udara terbuka selama 12 jam dan dicetak dengan ukuran diameter $5 \mathrm{~cm}$.

\section{Pembentukan Kalsium Fosfat dengan Variasi Waktu Kontak}

Pembentukan kalsium fosfat dilakukan dengan menggunakan reaktor sistem membran. Reaktor sistem membran dibagi menjadi tiga bagian, yaitu kompartemen bawah untuk larutan $\mathrm{CaCl}_{2} 1 \mathrm{M}$, kompartemen atas untuk larutan $\mathrm{KH}_{2} \mathrm{PO}_{4}$ 0,6 $\mathrm{M}$ dengan pH 9 dan diantara kompartemen atas dan bawah terdapat membran selulosa bakterial. Pembuatan larutan $\mathrm{KH}_{2} \mathrm{PO}_{4}$ dengan $\mathrm{pH} 9$ dilakukan dengan menambahkan $\mathrm{NaOH}$. Proses pembentukan kalsium fosfat ini dilakukan pada temperatur kamar. Variasi waktu yang digunakan adalah 5, 6 ,12, 24, dan 48 jam. Produk yang diperoleh kemudian dicuci dengan akuades dan dikeringkan dalam desikator sampai diperoleh berat konstan.

\section{Karakterisasi Hasil}

Karakterisasi hasil menggunakan Spektrometer FTIR untuk identifikasi gugus fungsi kalsium fosfat yang dihasilkan dan Difraksi sinar X (XRD) untuk mengetahui jenis, fase serta ukuran kristalit kalsium fosfat yang dihasilkan.

\section{Hasil dan Pembahasan}

\section{Sintesis Selulosa Bakterial}

Selulosa bakterial disintesis secara ekstrasel oleh Acetobacter xylinum yang merupakan bakteri aerob. Bakteri Acetobacter xylinum dapat menghasilkan selulosa bakterial karena memiliki enzim isomerase yang dapat mempolimerisasi gula hingga 200.000 molekul glukosa dalam bentuk rantai 1,4 $\beta$-glikosida. Selulosa bakterial yang dihasilkan berupa hidrogel (gambar 1). Selulosa bakterial berupa hidrogel karena memiliki kadar air tinggi yakni sebesar 98-99\%. 


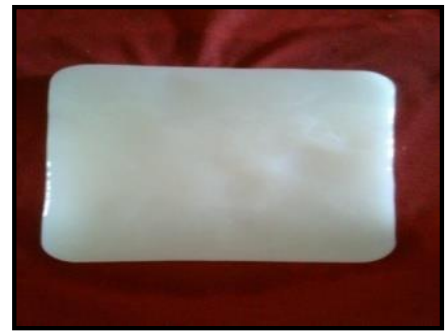

Gambar 1. Selulosa bakterial hasil inkubasi

\section{Pembuatan Membran Selulosa Bakterial}

Pembuatan membran selulosa bakterial adalah melalui proses pengeringan selulosa bakterial berupa hidrogel. Proses pengeringan merupakan proses penyusutan selulosa atau penghilangan air. Membran selulosa bakterial yang telah dikeringkan, dicetak dengan diameter $5 \mathrm{~cm}$, diukur ketebalannya kemudian ditimbang (gambar 2). Membran yang diperoleh berwarna putih, permukaannya halus dan tidak berkerut dengan tebal $0,8.10^{-2} \mathrm{~cm}$ dan berat membran 2,446.10 - 3,152.10-1 gram.

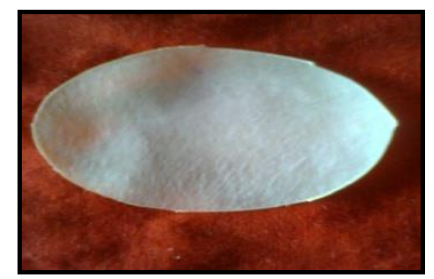

Gambar 2. Membran selulosa bakterial $5 \mathrm{~cm}$

\section{Pembentukan Kalsium Fosfat dengan Variasi Waktu} Kontak

Pengaruh waktu terhadap pembentukan kalsium fosfat adalah sebagai berikut:

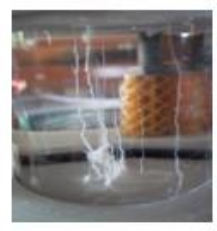

(a)

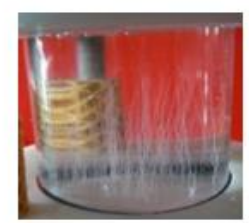

(d)

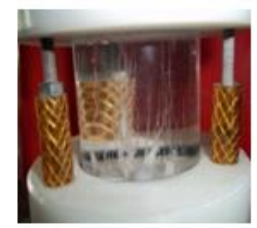

(b)

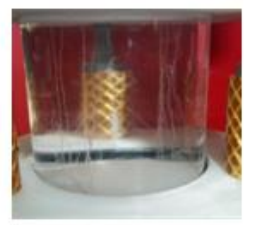

(c)

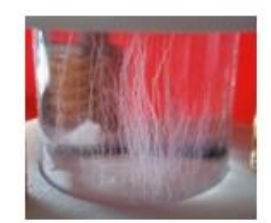

(e)

Gambar 3. Produk kalsium fosfat yang terbentuk variasi waktu (a) 5 jam, (b) 6 jam, (c) 12 jam, (d) 24 jam (e) 48 jam

Variasi waktu 5, 6, 12, 24 jam menghasilkan bentuk kalsium fosfat berupa fibrous sedangkan variasi waktu 48 jam menghasilkan bentuk kalsium fosfat berupa fibrous dan partikulat.

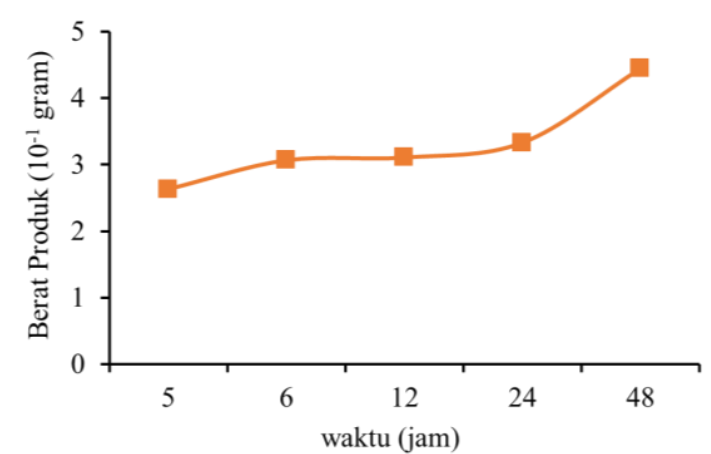

Gambar 4. Grafik perbandingan variasi waktu terhadap berat produk

Berdasarkan gambar 4, semakin lama waktu yang digunakan untuk pembentukan kalsium maka berat produk kalsium fosfat yang dihasilkan semakin meningkat. Meningkatnya berat produk menunjukkan bahwa waktu sangat berpengaruh pada pembentukan kalsium fosfat.

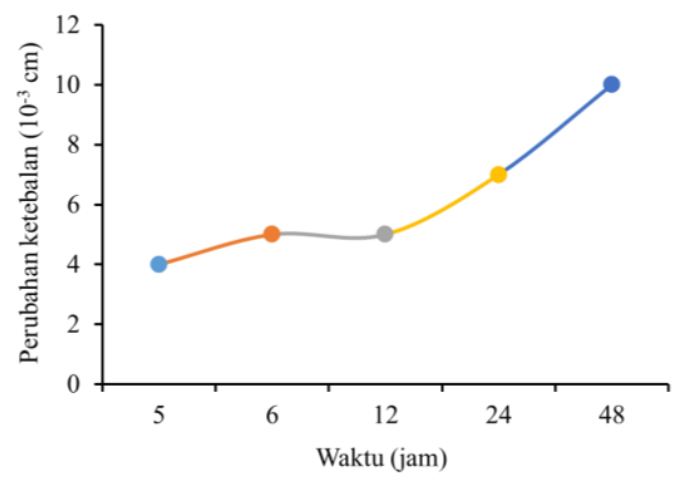

Gambar 5. Grafik perbandingan variasi waktu terhadap perubahan ketebalan membran

Grafik perbandingan variasi waktu terhadap perubahan ketebalan membran menunjukkan bahwa waktu berpengaruh terhadap ketebalan membran cenderung naik. Hal ini disebabkan karena terjadi swelling atau penggembungan terhadap ketebalan membran. Selama proses difusi berlangsung, ion $\mathrm{Ca}^{2+}$ akan terus berdifusi ke atas meninggalkan membran kemudian bereaksi dengan ion $\mathrm{PO}_{4}{ }^{3-}$ membentuk kalsium fosfat dan digantikan oleh molekul-molekul $\mathrm{H}_{2} \mathrm{O}$ sehingga ketebalan membran akan naik.

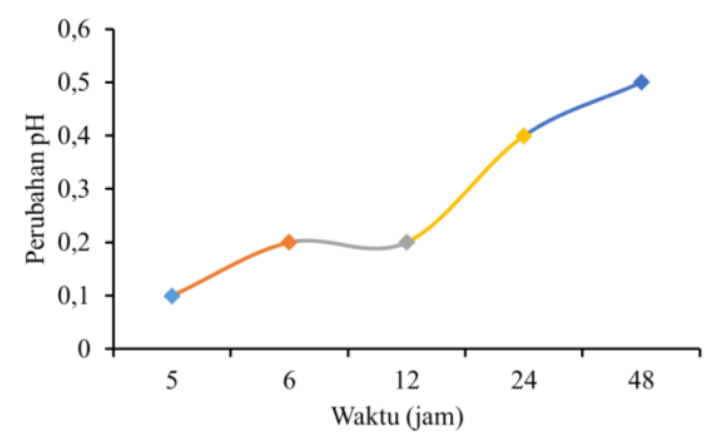

Gambar 6. Grafik perbandingan variasi waktu terhadap perubahan $\mathrm{pH}$ 
Gambar 6 menunjukkan, semakin lama waktu difusi ion $\mathrm{Ca}^{2+}$ menuju ion $\mathrm{PO}_{4}^{3-}$ dalam pembentukan kalsium fosfat maka $\mathrm{pH}$ sistem mengalami penurunan. Penurunan $\mathrm{pH}$ disebabkan karena semakin banyak ion $\mathrm{OH}^{-}$yang merupakan penyumbang nilai $\mathrm{pH}$ basa telah berikatan dengan ion $\mathrm{Ca}^{2+}$ dan ion $\mathrm{PO}_{4}^{3-}$ membentuk kalsium fosfat dan $\mathrm{H}_{2} \mathrm{O}$. Penurunan nilai pH dari larutan $\mathrm{KH}_{2} \mathrm{PO}_{4}$ didukung oleh semakin banyaknya produk kalsium fosfat yang terbentuk dengan meningkatnya waktu pembentukan kalsium fosfat (gambar 3).

\section{Karakterisasi Hasil}

Hasil analisis produk kalsium fosfat menggunakan spektrometer Fourier Transform Infrared (FTIR) adalah sebagai berikut:

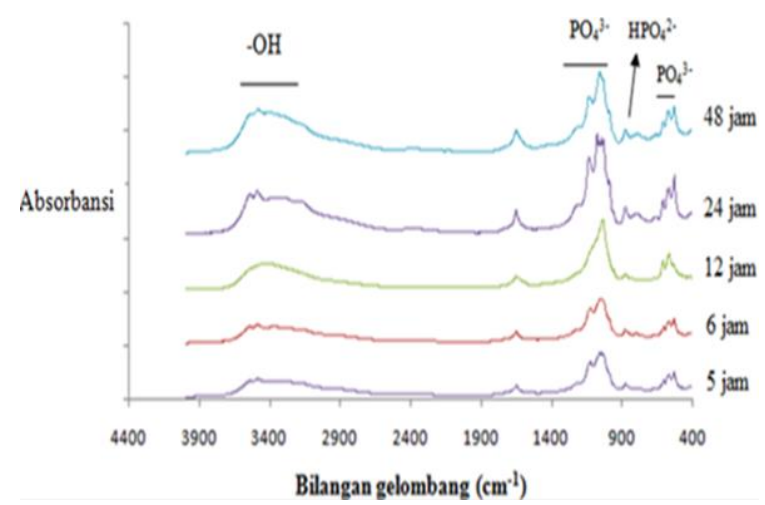

Gambar 7. Gabungan spektra FTIR kalsium fosfat variasi waktu

Absorbansi tertinggi tipe vibrasi ulur $\mathrm{O}-\mathrm{H}$ dari $\mathrm{H}_{2} \mathrm{O}$ sebesar 0,2 dimiliki oleh sampel 24 jam dan tipe vibrasi ulur $\mathrm{O}-\mathrm{H}$ dari $\mathrm{H}_{2} \mathrm{O}$ dan $\mathrm{HA}$ dengan absorbansi tertinggi adalah sampel 48 jam. Hal ini didukung oleh penurunan $\mathrm{pH}$ tertinggi pada pembentukan kalsium fosfat variasi waktu 24 jam dan 48 jam (gambar 6). Vibrasi tekuk H$\mathrm{O}-\mathrm{H}$ dari $\mathrm{H}_{2} \mathrm{O}$ dimiliki oleh sampel variasi waktu 24 dan 48 jam. Karbonat dengan absorbansi paling tinggi adalah pada sampel 6 jam dan 24 jam. Vibrasi ulur $\mathrm{P}-\mathrm{O}$ dari HA memiliki absorbansi tertinggi pada sampel 24 jam. Tipe vibrasi $\mathrm{PO}_{4}{ }^{3-}$ memiliki absorbansi tertinggi pada sampel 24 jam. Absorbansi tertinggi vibrasi $\mathrm{H}-\mathrm{O}-$ $\mathrm{P}$ dalam $\mathrm{HPO}_{4}$ adalah pada sampel 24 jam. Setiap sampel variasi waktu memiliki tipe vibrasi ulur $\mathrm{O}-\mathrm{P}-\mathrm{O}$ dan $\mathrm{P}-$ $\mathrm{O}$ dari $H A$ dan intensitas absorbansi tertinggi pada sampel 48 jam. Tipe vibrasi khas O-P-O dalam TCP dimiliki sampel 5 dan 6 jam. Berdasarkan spektra FTIR, jenis kalsium fosfat yang mungkin terbentuk adalah kalsium hidrogen fosfat dihidrat (CHPD), trikalsium fosfat (TCP), dan hidroksiapatit (HA).

Analisa XRD kalsium fosfat mendukung analisa FTIR untuk menentukan jenis kalsium fosfat yang dihasilkan serta menunjukkan jenis, fase dan ukuran kristalit produk kalsium fosfat yang dihasilkan. Jenis kalsium fosfat yang dihasilkan adalah berdasarkan sudut $2 \theta$ yang terbentuk pada difaktogram XRD dan disesuaikan dengan JCPDS International Center for Diffraction Data (JCPDS-ICDD).

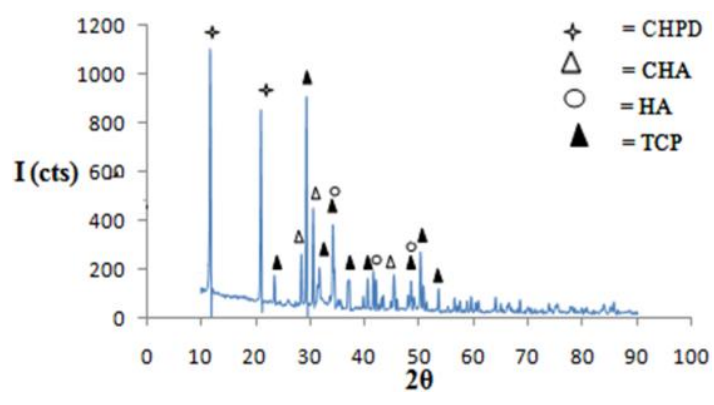

Gambar 8. Difaktogram XRD kalsium fosfat variasi waktu 5 jam

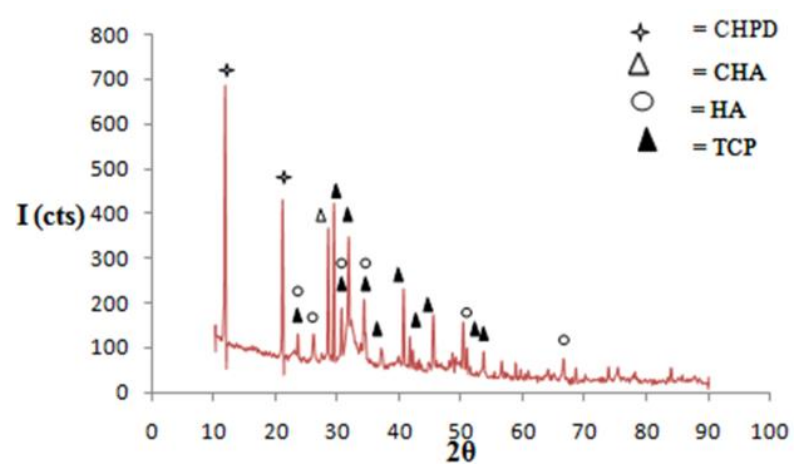

Gambar 9. Difaktogram XRD kalsium fosfat variasi waktu 6 jam

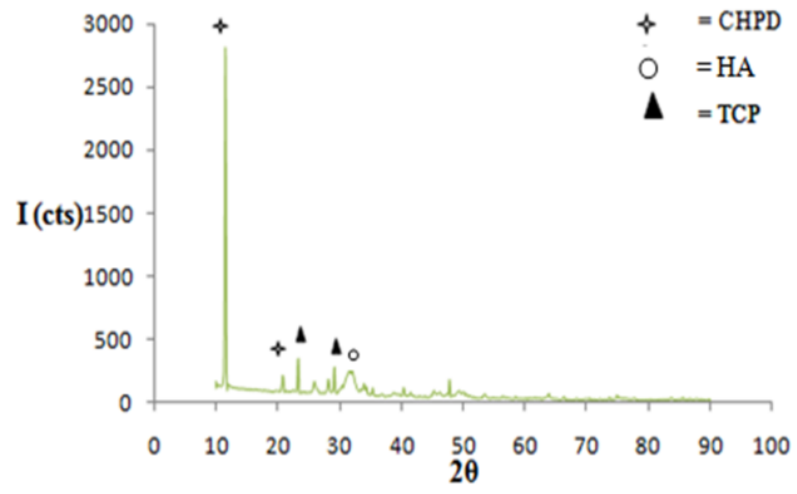

Gambar 10. Difaktogram XRD kalsium fosfat variasi waktu 12 jam

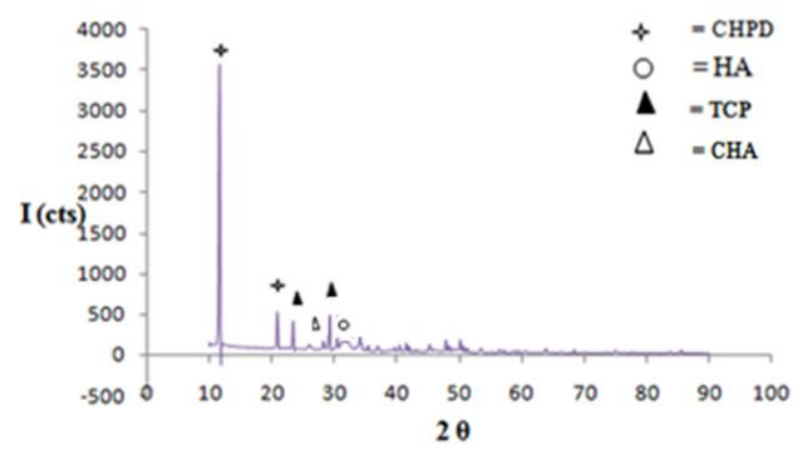

Gambar 11. Difaktogram XRD kalsium fosfat variasi waktu 24 jam 


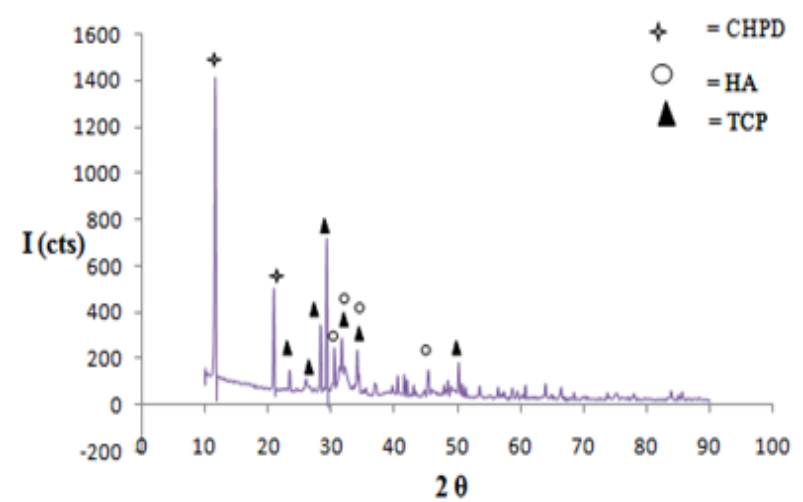

Gambar 12. Difaktogram XRD kalsium fosfat variasi waktu 48 jam

Difaktogram XRD menunjukkan bahwa intensitas jenis kalsium fosfat yang terbentuk setiap variasi waktu adalah berbeda-beda. Pada tiap variasi waktu, intensitas tertinggi dimiliki oleh sudut $2 \theta=11^{\circ}$ yang menunjukkan adanya senyawa CHPD. Berdasarkan penelitian Dickenhorst (2010), TCP dapat bereaksi dengan monokalsium fosfat monohidrat (MCPM) membentuk CHPD.

$$
\beta-\mathrm{Ca}_{3}\left(\mathrm{PO}_{4}\right)_{2}+\mathrm{Ca}\left(\mathrm{H}_{2} \mathrm{PO}_{4}\right)_{2} \cdot \mathrm{H}_{2} \mathrm{O} \rightarrow 4 \mathrm{CaHPO}_{4} \cdot 2 \mathrm{H}_{2} \mathrm{O}
$$

Penurunan intensitas CHPD pada variasi waktu 6 dan 48 jam, menunjukkan adanya transformasi CHPD. Hal ini ditunjukkan dengan semakin meningkatnya jumlah hidroksiapatit (HA) yang terbentuk pada variasi waktu 6 dan 48 jam. Variasi waktu 12 dan 24 jam menunjukkan peningkatan intensitas puncak $11^{\circ}$ dibandingkan pembentukan kalsium fosfat pada variasi waktu 5 dan 6 jam sedangkan intensitas jenis kalsium fosfat yang lainnya adalah tetap. Meningkatnya intensitas CHPD menunjukkan semakin lama waktu pembentukan kalsium fosfat maka jumlah ion $\mathrm{HPO}_{4}^{-}$ sebagai pembentuk senyawa CHPD semakin banyak. Berdasarkan analisa FTIR dan XRD, jenis kalsium fosfat yang terbentuk pada variasi waktu 5, 6, dan 24 jam adalah CHPD, TCP, CHA dan HA sedangkan variasi waktu 12 dan 48 jam adalah CHPD, TCP, dan HA. Di setiap variasi waktu, senyawa CHPD adalah produk utama karena memiliki intensitas tertinggi dibandingkan jenis kalsium fosfat lainnya. Semakin lama waktu, fase kalsium fosfat adalah semakin semikristalin karena semakin lama waktu pembentukan kalsium fosfat maka partikel-partikel akan membentuk gabungan dengan partikel lain (aglomerat) sehingga susunan partikel menjadi kurang teratur (Jones, 2002). Keadaan tersebut menyebabkan sifat kristalin kalsium fosfat berkurang dan terjadi pelebaran garis pada difaktogram XRD.

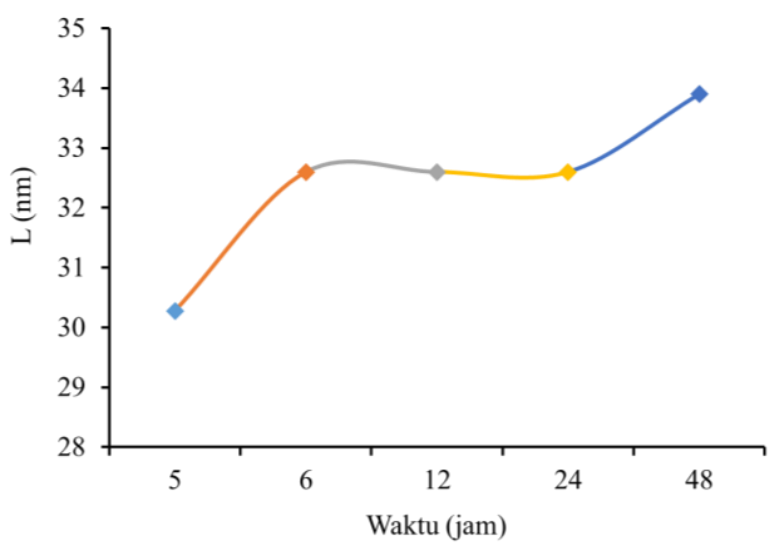

Gambar 13. Grafik perbandingan variasi waktu terhadap perubahan ukuran kristalit

Berdasarkan gambar 13, semakin lama waktu pembentukan kalsium fosfat maka ukuran kristalit cenderung semakin besar karena partikel-partikel akan membentuk gabungan dengan partikel lain (aglomerasi) dengan semakin lamanya waktu pembentukan kalsium fosfat yang digunakan.

\section{Kesimpulan}

Pembentukan kalsium fosfat menggunakan membran selulosa bakterial, pada variasi waktu 5, 6, dan 24 menghasilkan kalsium hidrogen fosfat dihidrat (CHPD), trikalsium fosfat (TCP), karbonat hidroksiapatit (CHA), dan hidroksiapatit (HA) dan variasi waktu 12 dan 48 jam adalah CHPD, TCP dan HA. Semakin lama waktu pembentukan kalsium fosfat, fase kalsium fosfat semakin semikristalin. Selain itu, semakin lama waktu, ukuran kristalit CHPD sebagai produk utama cenderung semakin besar yaitu variasi waktu 5 jam sebesar 30,28 $\mathrm{nm}$, variasi waktu 6, 12, 24 jam sebesar 32,60 nm dan variasi waktu 48 jam sebesar 33,90 nm.

\section{Daftar Pustaka}

[1] Burkhard Dickenhorst, Preparation and characterization of DCPD-forming calcium phosphate cements and of cement-protein drug microparticle composites for bone tissue engineering, Freie Universität Berlin,

[2] Mohammadreza Tahriri, Mehran Solati-Hashjin, Hossein Eslami, Synthesis and characterization of hydroxyapatite nanocrystals via chemical precipitation technique, Iranian Journal of Pharmaceutical Sciences, 4, 2, (2008) 127-134

[3] Jennifer L Giocondi, Bassem S El-Dasher, George H Nancollas, Christine A Orme, Molecular mechanisms of crystallization impacting calcium phosphate cements, Philosophical Transactions of the Royal Society of London A: Mathematical, Physical and Engineering Sciences, 368, 1917, (2010) 1937-1961 http://dx.doi.org/10.1098/rsta.2010.0006

[4] Asep Sofwan Faturohman Alqap, Low temperature hydrothermal synthesis of calcium phosphate ceramics: effect of excess Ca precursor on phase behavior, Indian Journal of Chemistry, 48, 11, (2009) 1492-1500 
[5] J Mulder, Basic principles of membrane technology, Springer Science \& Business Media, 2012.

[6] Barbara Surma-Ślusarska, Sebastian Presler, Dariusz Danielewicz, Characteristics of bacterial cellulose obtained from Acetobacter xylinum culture for application in papermaking, Fibres \& Textiles in Eastern Europe, 16, 4, (2008) 108-111

[7] Johnsy George, K. V. Ramana, S. N. Sabapathy, A. S. Bawa, Physico-Mechanical Properties of Chemically Treated Bacterial (Acetobacter xylinum) Cellulose Membrane, World Journal of Microbiology and Biotechnology, 21, 8, (2005) 1323-1327 http://dx.doi.org/1007/s11274-005-3574-0 